\title{
Effect of stress and professional burning on moral and ethical values in physiotherapy profession
}

\section{Uticaj stresa i profesionalnog sagorevanja na moralne i etičke vrednosti u profesiji fizioterapeuta}

\author{
Stevan Jovanovic, Biljana Stojanovic \\ Higher Education School of Professional Health Studies, Belgrade, Serbia \\ RECEIVED 06.03.2017 \\ ACCEPTED $\quad 16.05 .2017$
}

\section{ABSTRACT}

The principles of rehabilitation are based on holistic medicine considering physical, mental and social aspects of the patient. In recent decades, we have witnessed intensive changes through the entire medical profession, that are caused by the tremendous advances in science and technology. The communication process between therapist - patient, and between all members of the medical team requires sensitivity to the problems of the patient. It includs honesty, empathy, active listening, patience and also represent the guidelines for successful communication that are necessary for the creation of mutual trust. The state of disease and disability changes every man and reinforces a sense of personal weakness. The patient that is faced with the weakness, needs words of comfort and accepts the help of another person. For a better understanding of the patient's suffering and fears in a therapeutic procedure, it is necessary to activate the empathic power primarily achieve high quality communication with the patient. Communication in medicine is considered as a core skill. Knowledge and good communication skills are a prerequisite for quality work for many professions, especially medicine. According to numerous studies, physiotherapists are primary candidates for combustion at work because of close contact with customers in the work of physiotherapy. Physical therapists, who experience burning, feel helpless in their ability to help others, and can not create a quality relationship with their patients. The resulting changes are loss of empathy and ethical values that were most important features of health services for many decades.

Key words: stress, psychological; physical therapy modalities; psychology, social.

\author{
Stevan Jovanović, Biljana Stojanović \\ Visoka zdravstvena škola strukovnih studija u Beogradu \\ PRIMLJEN 06.03.2017. \\ PRIHVAĆEN 16.05.2017
}

\section{APSTRAKT}

Rehabilitacioni principi se temelje na holističkoj medicini te sagledavaju pacijenta s fizičkog, mentalnog i socijalnog aspekta. Poslednjih decenija svedoci smo intenzivnih promena, koje su uzrokovane strahovitim napretkom nauke i tehnologije kroz koje prolazi celokupna medicinska struka a samim tim i fizioterapeutska struka. Komunikacijski proces na relaciji fizioterapeut - pacijent, kao i između svih članova medicinskog tima zahteva osetljivost za probleme pacijenta, iskrenost, empatiju, aktivno slušanje i strpljivost. Navedene osobine ujedno predstavljaju i smernice uspešne komunikacije koje su nužne za stvaranje međusobnog poverenja sa bolesnikom. Bolest menja svakog čoveka i pojačava osećaj lične slabosti. Bolesnik suočen sa slabošću traži reči utehe i prihvata pomoć druge osobe. Za bolje razumevanje pacijentovih patnji i strahova u fizioterapijskom postupku nužno je aktivirati empatijske snage koje prvenstveno ostvarujemo kvalitetnom komunikacijom sa bolesnikom. Komunikacija u medicini smatra se osnovnom veštinom. Znanje i veštine kvalitetne komunikacije preduslov su kvalitetnog rada za mnoge profesije, posebno u medicini. Prema brojnim studijama fizioterapeuti su primarni kandidati za sagorevanje na poslu zbog bliskog kontakta u radu s korisnicima fizioterapije. Fizioterapeuti, koji iskuse sagorevanje, osećaju se bespomoćno u svojoj sposobnosti da pomognu drugima, osećaju umor te ne mogu stvoriti kvalitetnu vezu sa svojim pacijentima. Nastale promene u vremenu u kome živimo su i osetni gubitak etičkih vrednosti koje su bile najvažnija karakteristika zdravstvene službe mnogo decenija.

Ključne reči: stres, psihološki; modaliteti fizikalne terapije; psihologija, socijalna. 


\section{INTRODUCTION}

Physiotherapy is an area of physical medicine and rehabilitation and involves the diagnosis and resolution of dysfunction of motion and strengthening physical and functional abilities; restoration and maintenance of optimal physical functioning, optimum physical skills and optimal quality of life in relation to the movement, and health; and to prevent the onset of symptoms and progress impairment, functional limitations, disability that may arise disease, irregular functioning, different states or injuries. ${ }^{1}$ The importance of rehabilitation medicine and the physiotherapists is coming increasingly to the fore because of the increasing number of people of all ages with a variety of chronic and degenerative diseases, disabilities, disability or invalidity. ${ }^{2}$ The physiotherapist has a responsibility for the implementation of the physiotherapy, and must have knowledge and skills that allow him to set up a functional diagnosis and determine the physical therapy intervention. The physical therapist must also possess knowledge and skills that enable successful communication with the patient, his family and other members of the professional team. ${ }^{3}$ Also, he is maintaining the documentation on the forms of intervention and application parameters, as well as direct consequences of any intervention in the evaluation of functional status, such as the strength of muscle strength, durability, quality and range of motion in the joint. Nevertheless, the therapist must possess the knowledge and skills needed to evaluate the physiotherapy process, conducting research in physical therapy, which is based on "evidence based" approach i.e. on evidence-based practice ${ }^{3}$. Physiotherapists are playing an important role in the development of policies of physiotherapy profession and appropriate standards for the various elements of physical therapy practice in order to ensure the usefulness, accessibility and high quality in the provision of physiotherapy interventions. ${ }^{4}$ The realization of the physiotherapy mission requires that each individual possesses a specific therapist and complex cognitive, psychomotor and emotional behavior when providing care to patient / client and client/ patients family. ${ }^{4}$

\section{MORAL AND ETHICAL VALUES IN PROFESSIONAL WORK OF PHYSIOTHERAPISTS}

Ethics is the part of philosophy that studies and evaluates the moral value, origin and principles of morality. 5 Ethics investigates the origins of morality and moral objectives, but also a personal sense of moral volition and moral action. Strictly speaking, ethics is the theory of morality, while the moral validity criteria applicable to actions and practice ${ }^{6}$. The term "moral" has a dimension that makes it kind of practice, our work turns into valuable reality, that it is one fact in the field of social practice. Morality is a social fact ${ }^{7}$. Prerequisites for ethical behavior are: awareness, feelings that contain notions of sympathy and compassion, hope is a fundamental tenet of future morality, and its development and desirable ethical behavior, love - as the term is understood in a very broad sense of emotions and plays a role in the development of morality, but also in personal moral conduct and arises both from the personality, and from the relationship with the oth$\mathrm{ers}^{7}$. Ethics is very important for medicine, because as a scientific discipline it concerns about the man, his life, health, and preventing disease. It could be said that modern medical ethics is based on four basic principles: the principle of respect for life, principle of justice - non-discrimination on any basis, the principle of charity - the principle of humanity and the principle of respect for the personality of the patient ${ }^{6}$. Due to the nature of the medical profession, it develops specific relationship between health professionals and patients. In modern society, medical ethics does not require to physiotherapists only knowledge about diseases, prevention, diagnosis and treatment, but also knowledge of the acceptance of the patient as a person equal to themselves ${ }^{8}$. Researches about moral values in the work of physiotherapists in Serbia are very scarce but still it is known that, physiotherapist care and intervention must be two-way; physical and psychological ${ }^{9}$. Physiotherapist, unlike members of other medical professions, are in close contact with patients and therefore it is important to develop communication skills that are required in performing of their professional work $^{10}$. Communication skills and ability to understand the patient's problems are prerequisites for the creation of a relationship of trust and where it will be possible to transfer compelling messages about the importance and effectiveness of therapy ${ }^{11}$. Right at the beginning of the process of physiotherapy treatment, it is important to explain to the patient whether his illness is progressive, chronic and whether it requires continuity in treatment and controlling ${ }^{11}$. Physiotherapist must be ready to listen to the patient and to understand their needs and problems. The survey conducted among physiotherapists in 
Poland, showed that the largest number of respondents said that physiotherapists thanks to a well-established contact with the patients were given better results during the rehabilitation and only $15 \%$ of respondents reported that they were not good enough to establish contact with patients and had poorer results.10ln order to achieve such a harmonized relationship, physical therapists should develop good communication skills that enable them to better understand each patient ${ }^{12}$. In accomplishing high-quality interdisciplinary cooperation, health workers should have certain interdisciplinary competences, instruments and methods. In performing their professional tasks in a team, physiotherapists must be familiar with the methodology of work within their profession ${ }^{13}$. Physiotherapists in Serbia, should adhere to a methodology of work that was previously required to standardize and harmonize it with international standards and norms. In rehabilitation medicine teamwork is considered to be a cornerstone and can be described as a collective effort of many individuals who together performed a series of concrete tasks ${ }^{14,15}$. In interdisciplinary teams in healthcare, with members of other professions, they must cooperate and communicate professionally in order to optimize the patient's condition ${ }^{16}$. Research in the field of teamwork in physiotherapy in Serbia is almost non-existent. To achieve such a harmonized relationship, physical therapists should develop good communication skills to ensure a better understanding of each patient ${ }^{11}$. Some studies have shown that patients with neurological impairments require a greater commitment by their physiotherapist and greater understanding that comes from interpersonal communication ${ }^{17}$. The satisfaction of patients is affected by many factors, most of which derive from communication with healthcare professionals. Patient need is to feel the emotional balance in the relationship in order to increase efficiency in conducting the therapy. Most patient's dissatisfactions resulting from lack of communication physiotherapist with them during the treatment, which is then reduced only to the physical component $^{17}$. Communication with sick people is based on trust that is built through a quality relationship, active listening, conversation skills and empathy and words that will console patients. Patients are often full of fear and apprehension because it is a period of their life in which there is uncertainty for them. If nothing else, the physiotherapist can, give hope and a word of understanding to the patient ${ }^{18}$. Central part of the empathy is active listening. Each patient is an individual for himself and identifying patients' needs, is a challenge for physiotherapists, but not routine. To be more effective in empathy, physical therapists must constantly synchronize with their body language of their patients, and the verbal expressions that are used by their patients. With such beneficial ap- proach, patients will be more open and engaged in process of their rehabilitation. It has been observed that some patients reduce pain and became more tolerable and have become active participants in the program and thus "easier" patients because of their physiotherapists ${ }^{19}$. In physical therapy there is a close physical relationship between the physiotherapist and the patient. This sometimes involves touch in the form of assisted exercises, manipulation and mobilization of the body, and massage. In addition, the therapist meets with the patient during treatment in a dozen or more times, which is much more than the usual patient visits a general practitioner. Since physiotherapists are thereby required to plan, organize, manage and supervise the therapeutic process, a degree of communication between the patient and his physical therapist should be well above average in order to achieve successful rehabilitation. All these activities can affect the emotional involvement of physiotherapists. In order to achieve the relaxed state of their patients, the physical therapists must give a warm friendly approach which among other things contributes to the creation of trust ${ }^{10}$. The creation of such a harmonized relationship, can be established by physical therapists by developing good communication skills that is enabling them to better understanding each patient ${ }^{11}$. Today, the current topics about the crisis of the modern world, the lack of morality in society, which has not bypassed the health profession. Although the scientific debate often talks about the humanization of medicine, it can not be bypassed by very strong breakthrough of technology that is undoubtedly the strong support for the diagnosis of the disease but not the only cause for the lack of empathy with a physiotherapist. One of the important causes are stress and professional burnout of physiotherapist at work that results in a change of behavior towards the patient and the need for routine performance. This raises the issue what the ethical behavior is, because the society and physiotherapy practice is complex and raise many ethical questions ${ }^{11}$. Today moral crisis of society is inevitably causing erosion of professional morals. The newly established social paradox had an impact on the situation of physiotherapy which is to some extent marginalized profession. It is more than clear that fairness, justice, truth and knowledge neglected moral values, a fair, honest and working person is not an example to be followed ${ }^{20}$. Important feature that physiotherapist must have is patience, because the results of physical therapy in many patients are seen only after long and hard work with the patient. The physical therapist must be able to provide support and encouragement as well as being actively involved, especially when the patient is losing momentum and wants to give up because it is too heavy or depressed. It is essential for the therapist to be able to maintain good patient's re- 
sponse and the need, in order to implement measures aimed at a specific therapeutic aim but also to determine the manner and pace of work. In performing their professional tasks, for a physical therapist, it is not necessary to be physically strong, but is important to have endurance and good condition ${ }^{11}$. It is therefore necessary as soon as possible, every individual, but also institutionally and socially, to reduce the gap between what is prescribed and what is life. One of the possible ways of solving this moral crisis is the teaching of virtues that should be respected. Physiotherapy profession is as a result of experienced social changes which experienced professional formation and scientific foundation, while human and ethical dimension is almost neglected. It is important to say that listening to the others who requires emotional strength, patience, openness and desire to understand ${ }^{20}$. Physiotherapists sometimes forget that the question of the balance between science, technology and human warmth, compassionate human relationships, among other things can help in building identity and profession. "Humanity, warmth, compassion on the one hand, and the sciences on the other hand, in the treatment of patients never should come into conflict or compete among themselves" ${ }^{12}$. There is an Australian study, in which was conducted a survey of the physical therapists. On the basis of the work experience, the participants should have to give ratings about the characteristics that make high-quality and complete physical therapist. The results pointed out the importance of placing the patient at the center of their treatment and full attention to their individual needs and the work of the building of mutual trust in relation therapist - patient ${ }^{2}$.

\section{STRESS AND PROFESSIONAL BURNOUT OF PHYSIOTHERAPISTS}

Physical therapists often provide their services to patients with various diseases and dysfunctions that have emotional problems. Therefore, physical therapists often suffer from stress and job burnout. In order to avoid these cases, it is necessary to develop strategies that will enable coping with emotional difficulties in different situations. Individuals who believe that the external factors affecting happiness is more likely to develop symptoms of depression, anxiety and emotional exhaustion, and therefore be worse organized in working place ${ }^{23}$. The inestimable importance for physiotherapeutic practice is developing practical skills of emphatic behavior and awareness of the present moment. Patients should be more valued as a person, and encouraged in order to provide hope for a speedy recovery and confidence in their specialty. For those physiotherapists who are unable to empathize with patients are at high risk of job burnout, lack of energy and psychological phenomena problems ${ }^{24}$. Stress is a component of combustion because the combustion at work is prolonged response to chronic mental and interpersonal stressors on the working place. Stressors in medical practice is classified as a physical, psychological and social stressors. Those who distant themselves from work and do not have a quality level of motivation often experience symptoms of combustion. The symptoms include headache, sleep problems, loss of appetite, psychological problems (depression, anxiety) and the problems of interpersonal communication. One may encounter some behavior problems that result in negligence at work and ruthlessness toward patients $\mathrm{s}^{25}$. In contact with the patient the interpersonal and communication skills are of critical importance. Of all health professionals, physical therapists have the highest risk of burnout. Physical therapists often work with the patients who may be in the state of seriously deteriorated health and facing death ${ }^{25}$. Interaction with the sick requires a multitude of skills and special predisposition. Physiotherapists should focus their communication competence on understanding the patient's condition in order to jointly achieve the goals of therapeutical process ${ }^{25}$. Job burnout is characterized as physical or emotional exhaustion due to long-term stress and strain. The rush of combustion is described as a special loss of idealism, energy initiatives and future goals because of emotional saturation and exhaustion. Physical therapists can then suffer from mood disorders, sleep and difficulty in mental concentration ${ }^{25}$. Mental instability is accompanied by physical elements such as headache and indigestion. Physical therapists, who experience burning, feel helpless in their ability to help others, feel fatigue and therefore can not create a quality relationship with their patients. Compared with other medical professionals therapists are most vulnerable to the risk of occurrence of combustion are talking about and many studies conducted in Japan and Italy ${ }^{26}$.

- According to Maslach and Jackson combustion is categorized as:

- Emotional exhaustion which means a loss of energy due to the accumulation negative feeling related to the job.

- depersonalization that implies detachment from the people who are being treated.

- Lack of personal fulfillment that is described as a feeling of incompetence.

Emotional exhaustion commonly occurs when physi- 
cal therapists are dissatisfied with financial compensation for their work, then lack of support from superiors and defective opportunities for professional development. The emergence of depersonalization is associated with dissatisfaction due to low financial compensation, poor cooperation and communication with colleagues. When there is a lack of personal fulfillment, the causes are mostly related also to the bad payment, poor co-operative skills with supervisors and lack of opportunities for professional development. Combustion is the most commonly occurring in physiotherapists who work with children and young patients ${ }^{26}$. Physiotherapists who work in private practice frequently experience burning at work than those in the public sector. The reason probably lies in the fact that they are more in touch with their patients, unlike those in the public sector who fail to develop closer links with patients, but still the biggest causes of job burnout with a physiotherapist are low income and poor communication with associates and superiors. ${ }^{26}$ In professional cooperation with colleagues, empathy and will to succeed are essentials that could develop physiotherapy as a profession much faster and more efficiently than ever before. If these aspects are implemented at her through individuals. ${ }^{27}$ Individual in the profession is the one who is approaching the patient and puts his hands on him, leading him through the therapy and manage his body in the healing process. It is important to connect with the patient in order to meet the complete medical services because therapists are human first, and then professionals. ${ }^{27}$ Physiotherapy offers great opportunities and that it could deal with competition in the market field, physical therapists need to work on the integration of all aspects that are necessary for that. ${ }^{27}$ If the treatment does not contain characteristics that are associated with a true desire to get to know the patient and understanding his perspective, there is a chance that treatment will be incomplete. It often happens that physical therapists that are frustrated and the patients that are angry and aggressive which complicates further interaction and possibly lead to refusing of treatment. The patient as a person must be at the center of all the events going on around him and because of him. ${ }^{28}$ Cole and McLean are standing out the true connection and relationship between the physiotherapist and reasonable patients through cooperation, communication, empathy and respect because in this way develop and relational and interactive component of relationships and an atmosphere in which the treatment is carried out and therefore, treatment is easier for both sides. ${ }^{28}$ According to the numerous studies, physiotherapists are primary candidates for combustion at work because of close contact with customers in the work of physiotherapy. All studies have shown that pressures related to the lack of time, the saturation of work and conflicts that spawn from working with "difficult" patients usually caused by combustion. Physiotherapists who experience combustion have usually just started their professional career. In order to diminish the risk of combustion, it is necessary to have the emotional support at work from colleagues and superiors ${ }^{29}$.

\section{CONCLUSION AND PROPOSED MEASURES}

The most difficult and dangerous crisis of a society is precisely a crisis of morality. It devalues the religious, spiritual, human values and generally leaves a moral wasteland. Physiotherapy profession has not escaped from the moral collapse that shattered the fundamental moral values (honesty, truth, justice and the human relationship to man). This is the reason why in modern physiotherapy specialists should have the necessary competences such as knowledge and skills physiotherapy profession, but at the same time should be effective communicators, appraisers of physiotherapy process, educators of younger generations and holders of research processes. It is clear that in a modern and advanced society emerge and new physiotherapy methods and techniques supported by technological and scientific developments and that the classic relationship therapist - patient is seriously changing. Paternalistic model creates a company with a holistic approach. A holistic approach involves teamwork and team work can be described as a collective effort of many individuals who together perform a series of specific tasks. Communication is especially important determinant of teamwork. The tasks that are put for the experts in teamwork in which a patient in the center, beyond the capabilities of the each individual but every member has a specific role to play and must abide by certain norms of professional conduct. This is the point where an important role is played by a good quality of communication that will directly affect the atmosphere in the team, in what way and how much will be cooperation and interaction, the adequate leadership, and therefore the motivation of team members. But how physical therapists can successfully apply a holistic approach in their work within a team, if there is awareness about the fact that the existential and moral crisis affecting all areas of human activity, and that the physiotherapeutic professions lived due to transitional problems which focuses on expertise in the team, while human and ethical dimension almost neglected. Lack of good communication in human relationships is overwhelming productivity at work.

Experts say that one of the preconditions for successfully conducting business is consistent treatment of colleagues. The hallmark of a good team is omnipres- 
ent feeling of support, security and confidence, whereby members can rely on each other in difficulties and download creative risks, confident in the support of his associates. The following basic rules of interpersonal relationships in the workplace develop key performance of work team and the development of self-confidence among physiotherapist. To help colleagues preserve its professional reputation is one of the reputed quality of good colleagues in the team. It would certainly be a continuous exercise and development of fundamental moral values such as justice, truth, honesty, wisdom, love, work, patience, modesty, caring, empathy and human warmth creating a positive atmosphere in the team work, a better connection that would have an impact on the success and satisfaction of the individual within the team. Physiotherapists have to cross the boundaries of current practice; in the future they hould build their professional and ethical views on case studies encountered in clinical practice. Physical therapists should be able in the future to disclose their ethical problems in medical journals open the problems of physiotherapy, which would compete with the marginal position in the system of evaluation profession. 


\section{REFERENCES}

1. Hall C. Introduction to therapeutic exercise and the modified disablement model. In: Hall CM, Brody LT, eds. Therapeutic exercise: moving toward function. 2nd ed. Philadelphia: Lippincott Williams and Wilkins, 2005: 1-4.

2. Bobinac-Georgievski A. Rehabilitacija u zajednici kao proces integralne skrbi za osobe s fizičkim onesposobljenjem. Sažetak radova. Drugi kongres s međunarodnim sudjelovanjem: Menadžement u zdravstvu. Zagreb, 1997: 91-94. (apstrakt).

3. Porter SB, Tidy NM, eds. Tidy's physiotherapy. 15th ed. Edinburgh: Sanuders Elsevier, 2013.

4. Physiotherapist.Ottawa: Foreign Credentials Referral Office, 2009.

5. Radišić J. Medicinsko pravo. Beograd: Pravni fakultet Univerziteta Union, 2008

6. Nenadović M, ur. Medicinska etika. Kosovska Mitrovica : Medicinski fakultet, 2007

7. Babić J. Etika i moral.Theoria 1 2008; 51: 35-48.

8. Matulić T. Bioetika. Zagreb: Glas Koncila, 2001.

9. Spiro H, McCrea Curnen MG, Peschel E, St James D. Empathy and the practice of medicine : beyond pills and the scalpel. New Haven: Yale University Press, 1996.

10. Matyja A, Stoj K. Interpersonal communication in medical profession on the example of physiotherapists. Pol J Public Health 2015; 124: 125-129.

11. Ofri D. What doctors feel: how emotions affect the practice of medicine. Boston: Beacon Press, 2013.

12. Higgs J, ed. Clinical reasoning in the health professions. Amsterdam: Elsevier Butterworth-Heinemann, 2012.

13. Vyt A. Interprofessional and transdisciplinary teamwork in health care. Diabetes Metab Res Rev 2008; 24: 106-9.

14. Gillespie BM, Chaboyer W, Longbottom P, Wallis M.The impact of organisational and individual Factors on team communication in surgery: a qualitative study. Int J Nurs Stud 2010; 47: 732-41.

15. Lerner S, Magrane D, Friedman E. Teaching teamwork in medical education. Mt Sinai J Med 2009; 76: 31829.

16. Hall P, Weaver L. Interdisciplinary education and teamwork: a long and winding road. Med Educ 2001; 35: 867-75.
17. Almeida R, Nogueira L, Bourliataux-Lajoine $S$. Analysis of the user satisfaction level in a public physical therapy service. Braz J Phys Ther 2013; 17: 328-35.

18. Garmaz J, Mrdeša-Rogulj Z. Neka načela u komunikaciji s bolesnikom. Služba Božja 2013; 3: 319-33.

19. Ringvold ML, Svensen AR. Implementing cognitive behavioural approach in student's clinical practice: third physiotherapy student's experiences. Eur J Physother 2013; 15: 160-5.

20. Covey SR.The 7 habits of highly effective people. Habit 4, Think win - win. Provo: Franklin Covey, 2006.

21. Kalauz S. Sestrinska profesija u svjetlu bioetičkog pluriperspektivizma. Zagreb: Pergamena, Hrvatska komora medicinskih sestara, 2011.

22. Aguilar A, Stupans I, Scutter S, King S. Exploring the professional values of Australian physiotherapists. Physiother Res Int 2013; 18: 27-36.

23. Wilski M, Chmielewski B, Tomczak M. Work locus in control and burnout in Polish physiotherapists: the mediating effect of coping styles. Int J Occup Med Environ Health 2015; 28: 875-89.

24. Spandler H, Stickley T. No hope without compassion: the importance of compassion in recovery-focused mental health services. J Ment Health 2011; 20: 555-66.

25. Sliwinski Z, Starczynska M, Kotela I, Kowalski T, Krys-Noszczyk K, Lietz-Kijak D, et al. Life satisfaction and risk of burnout among men and women working as physiotherapists. Int J Occup Med Environ Health 2014: 27: 400-12.

26. Pavlakis A, Raftopoulos V, Theodorou M. Burnout syndrome in Cypriot physiotherapists: a national survey. BMC Health Serv Res 2010; 10: 63. (doi: 10.1186/14726963-10-63).

27. Ohman A, Hagg K, Dahlgren L. Competent women and competing professions - physiotherapy educators' perceptions of the field. Advances in Physiotherapy 1999: 1: 59-72. (doi: 10.1080/140381999443447)

28. Kayes NM, McPherson KM. Human technologies in rehabilitation: 'Who' and 'How' we are with our clients. Disabil Rehabil 2012; 34: 1907-11.

29. Mandy A, Saeter M, Lucas K. Burnout and self-efficacy in Norwegian physiotherapists. Int J Ther Rehabil 2004; 11: 251-7. 